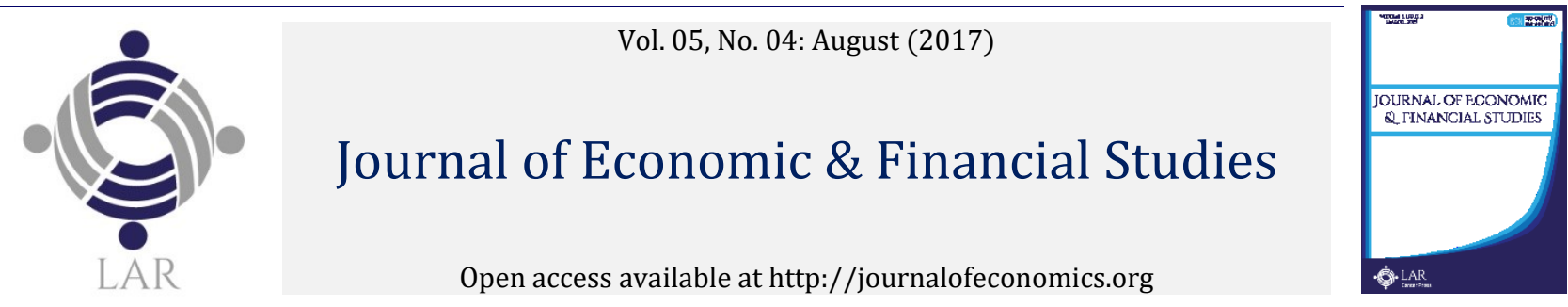

\title{
Total quality management (TQM), organizational characteristics and competitive advantage
}

\author{
A.S. H. Yousifa, Najm A. Najm a*, Jasser A. Al-Ensour a \\ a Al Zaytoonah University of Jordan. \\ *Corresponding author's email address: najim_abood@yahoo.com
}

\section{A R T I C LE I N F O}

Received: 21-07-2017

Accepted: 14-08-2017

Available online: 15-08-2017

Keywords:

Accreditation;

Competitive advantage;

Innovation;

ISO-9000;

Reputation;

Strategic quality vision;

TQM dimensions.

JEL Classification :

A11; L22; M10.

(C) 2017 The Authors. This is an open-access article under the terms of the Creative Commons Attribution License 4.0, which allows use, distribution and reproduction in any medium, provided the original work is properly cited.

DOI: http://dx.doi.org/10.18533/jefs.v5i04.293

\begin{abstract}
A B S T R A C T
We investigate two issues. The first is to determine the impact of TQM dimensions of a medical care system (quality system, quality leadership, medical and sanitary staff, relationship with patient, relationships with suppliers, and continuous improvement) on the hospital competitive advantage (innovation, competitive benchmarking) in sample Jordanian hospitals. The second is to explore the moderating effect of two basic organizational characteristics: the size and the age of a hospital, on the relationship between TQM dimensions and competitive advantage. Our finding indicates that five TQM dimensions (QS, QL, RP, RS, and $\mathrm{CI}$ ) have a positive impact on hospital innovation and reputation. This result is compatible with the main findings of many previous field studies. (Prajogo and suhal, 2003; Hung et al., 2010; Abrunhosa and Sa, 2008; Bon and Mustafa, 2013, Silva et al., 2014). This result could be attributed to a continuous improvement of hospital services quality (the sixth of the main dimensions of TQM). Continuous improvement (CI) is synonymous to innovation because both imply changes and modifications to health service.
\end{abstract}

\section{Introduction}

Historically, the interest in productivity and efficiency concepts was precedent to that of the quality concept. Therefore, the progress that was achieved during the past decades concerning production size was much greater than that of the quality field. This fact may be the main reason behind Jouran's statement that he has released in his study published by Harvard Business Review (1992) when he argued that "the $20^{\text {th }}$ century is the productivity century and the $21^{\text {st }}$ century is the quality century". Consistent with that it might be rational to add that the last quarter of the $20^{\text {th }}$ century has witnessed the early interest in quality concept of the manufacturing sector. The 40 s of the last century has witness the emergence of service quality concept, while the 80s of that century has witness the appearing of electronic service quality concept.

Relying upon the previously mentioned evolution, it might be rational to say that the 21 st century will witness the concern in new patterns of quality at the top of which: the quality of knowledge, intangible assets, human capital and perhaps spiritual assets. The past five decades has testified a radical shifting from interest in quality concept. This was plainly appearing especially during the 80's of the last century when the American and the European companies were badly affected by many dramatic developments in the business environment such as: quality based comprehensive competition, the Japanese quality-based competition success. These developments have seriously sidetracked attention toward new quality perspectives, objectives and improvement relying upon a new strategic vision that replacing the old practices of operational plans. This was plainly confirmed by Jouran when he distinguished between two quality perspectives: "big and little quality". This is simply meant that the interest in quality has been expanded to comprised services as well as industry. 
The evolution of quality concepts is well presented by many key trends. These trends are diversifying from conformity to standards or specifications to fitness for use. This development means radical shifting from production approach to marketing sovereignty approach. This, was behind the considerable evolution in the concept of the defect level as it was evolved from "Allowable defect" (i.e. $\pm 3 \sigma$ quality level) to "zero defect" (i.e. $\pm 6 \sigma$ quality level). This essentially means shifting from partial loss defect (losses at company level) to total loss defect (losses at society level) while Tagushi methods, moving from historical self-comparison quality concept to competitive benchmarking quality concept. Finally, it reflects a shifting from the quality of industry, (goods and hard process) to the quality of soft business, relationships and soft interactions of the service sector.

\section{The emergence of quality}

At the early stages of the industrial revolution, the main focus at that time was on production quantity and scale accompanied by the circulation of shoddy goods and products. This was the most common spectacle that was dominating the field of business for a long period of time. During that period quality concept was treated as a luxury object that very few people concerned about it therefore it was rarely used in the production and services sectors. This situation was altered after a series of important changes that were taken place in the industry and services sectors accompanied by major changes in society culture. By the end of the first half of the $20^{\text {th }}$ century, the quality concept has received a considerable attention from a great majority of companies' management. This development was followed by some extra important improvements that were taken place during the second half of the 20th century. These developments have been illustrated by six major transformations including:

- Shifting from producer market (where production is much less than demand: $(P<D)$ to consumer market (where demand is much less than demand: $(\mathrm{D}<\mathrm{P})$ due to an intensive competition and multicompetitors markets.

- Moving from quality as an operational factor (i.e.; as a major part of efficient operations altering from economies of scale to economies of scope) to quality as a strategic factor (i.e. as a major business process to achieve a competitive advantage) (Goldhar and Jelinek, 1983; Mehra et al., 2001).

- Transformation from quality as a conformance to specifications (Crosby, 1979), to quality as a fitness for use or purpose. (Crosby, 1979), (Evans, 1997), (Joran,1999), (Reid \& Sanders, 2002), (Finish, 2007), (Heizer \& Render, 2011) (Srevenson, 2011)

- Transition from quality of good (as a physical thing) to quality of service (where service is an activity that provides utility to customer). The five gaps model was a magnificent contribution to the development of service quality concept. (Parasuraman et al., 1985, 1988, 1991, 1993, 1994).

- Altering from the quality of a tangible physical world to the quality of an intangible e-service world (Aboyassin el al, 2017).

\section{$2.1 \quad$ Total quality management}

Total quality management (TQM) is the distinguished managerial innovation according to business vision and management leaders (Birinshaw et al., 2008), (Munizu, 2013). It is of equal important in comparison with the technological innovations, including the innovation of the spinning loom and the steam engine. This is, mainly, due to the essential achievement by quality management that has been considered as a significant milestone in the process of eliminating waste of resources, protecting customer from shoddy products or services and protecting the whole society from serious losses of jobs. No doubt that Total Quality Management (TQM) was the fruit of a long efforts backed by what has been achieved of considerable developments. This was prior to the maturity of many other concepts and practices that have been evolving over a long period of time before becoming an integrated system for the whole company. Generally speaking, TQM has many meanings and merits. It might mean a "strategic totalitarian vision of quality", which is an approach based on the company policy and considers quality as the responsibility of all company employees including top management team. It is an integrated methodology for conformity of standards and market requirements to achieve better quality, or it is a philosophy of continuous improvement (Kaizen). In this regard, TQM is considered as a process through which all managers and employees must participate in the efforts for products \& services continuous improvement. According to TQM, the "total" refers to the whole organization as a holistic entity which is highly different from any partial things or concepts. In this context, QM is the relevant approach to a continuous improvement process or "The Berger's five types or designs for continuous improvement", total customer satisfaction, total employee involvement, and total competitive benchmarking in industry and market. (Berger, 1997) (Sparks and Legault, 1993) (Mehra et al., 2001) (Reed et al,2000) (Pramuka \& Adawyah, 2012)

TQM has been significantly contributing to business achievements in term of financial and non-financial results. In addition to that it also has been significantly contributing to all kinds of efforts of production wastereduction at company level. This was the main element behind the raison of customer- focus concept that has become a pivot starting point of all types of activities at company level. This development assists companies to rationalize their production outputs through marketing activities. TQM has also contributed feasibly and widely to quality measurement and improvements methods, through various forms which were crowned by 
standardization as a type of quality measurement that comparing company quality against its best competitors in the market. All these developments have maintained a continuous improvement of the quality concept and its related practices to become a nonstop process to enhance quality supported by the participation of all departments and individuals. This is what has, actually, made the holistic integrated vision of quality at company level a prior condition to the success of any quality improvement efforts or programs. Hence, this was the essential reason behind considering quality as high important competitive priority as cost, efficiency, flexibility, diversity, reliability, reliable delivery time, and innovation. (i.e. Systematic development of new products). (Satish \& Srinivasan, 2010).

Despite the great importance of TQM and its major contribution to the movement of ensuring a continuous enhancement of, process, products, and services quality, the concept is still confronting many obstacles and receiving criticisms related to its high cost caused by the poor relationships between cultural restrictions and company performance standards. Tornow and Wiley (1991) have confirmed the negative relationship between TQM implementation and customer satisfaction. Iaquinto, 91999) has concluded that there is a negative relationship between company's winning quality prizes and their performance. Powell (1995) asserted that most TQM features and elements, (such as quality training, process improvement, and standardization) did not lead to competitive advantage achievement (Mehmood et al , 2014).

\subsubsection{Three perspectives on TQM}

The theoretical framework and operational system of quality management has witnessed a group of significant developments with continuous improvements. Companies, centers of expertise, consulting firms, and researchers have been contributing significantly to the development of quality in terms of concept, system application management, and accreditation of certificates and awards application process. This broad interest in TQM has contributed reasonably to consider it as a competitive priority for all concerned parties. Rely upon this evolution of the concept; it might be useful to distinguish between three important perspectives of TQM which are as follow:

- ISO 9000-2008 and 2015: The intent of this perspective is to develop a standardized quality management system based on general and specific requirements (i.e.; quality management system, management responsibility, resource management provisions, infrastructure, product realization, and Measurement, analysis and improvement) (Tricker, 2010). BY unifying and deploying quality specifications worldwide, ISO 9000 group is treating all types of companies at all economic sectors similarly, (small-big, manufacturing-service in developed or developing countries) in term of language, application inquires ,and necessary requirements for ISO certificate application purposes (Sun et al, 2004). ISO 9000 family was considered as an important step for building a quality management system, because it was relying upon the development of quality concept and its applications in very diversified economic sectors, including health care and hospitals. Although ISO 9000-2008 has many advantages but, it has been criticized regarding its implementation process such as: the needs huge paperwork, bureaucratic procedures with intensive formality (Hoyle, 2011), (Barnes, 2000). It is an impersonal system, without any direct value-add, threats the company flexibility, badly affects company speed in responding to environmental changes, costly, timeconsumption, very complex due to its huge number of procedures, poor coordination between members of the implementation group, and hampering organizational change. What is interesting in this context is the continuous increase of the demand for ISO certificate application which has negatively affected the company's total revenue since the application cost in some cases has exceeded the company total revenue. In addition to that, many experts, nowadays, believe that pursuing the process of obtaining the ISO certificate has become the main concern of top management team and organizations at all economic sectors. This means paying little or no attention to quality enhancement process. (ISO, 2008; 2015). In conclusion, this approach aims at developing a standardized quality management system.

Accreditation certificates: Accreditation is a series of activities that are, usually, executed by highly specialized institutions to evaluate hospital quality system, based on pre-defined comprehensive standard specifications of hospital facilities, jobs, staff, patient services, hospital commitments to health risks reduction and improvement of health care services quality at the hospital (JCI, 2011). Accreditation is a management challenge process begins by specific pre-determined demands and a measurable package of objectives that must be achieved by hospital management to be able to build a quality management system. These activities need be completed to be able to obtain a certificate. The accreditation provides strong evidence that in term of facilities and patient care, services and relationships a hospital has achieved an appropriate level of health care services quality and safety. Accreditation program can be implemented at international level by the Joint Commission International (JCI) and at national level. In Jordan, the accreditation program is under the responsibility of the health care accreditation council (http://hcac.jo/en-us). Table 1 shows that the ICRC oversees the accreditation program, which includes two sections of 14 standards. The Jordanian accreditation body is conducting the national accreditation program, that comprises 15 standards including: patient and family rights, access and continuity of care, patientcare, diagnostic services, medication use and pharmacy services, infection prevention and control, 
environmental health, and safety, support services (housekeeping, food, laundry), quality improvement, medical records, human resource management, management and leadership, medical staff, nursing services, education and training.

- Researchers contributions to TQM elements: Although researchers are not unified regarding their viewpoints to the common dimensions of total quality management, however, it would not be that difficult to find some common TQM dimensions such as: strategic quality vision, quality and engagement of staff, relationship with customer, relationships with suppliers, continuous improvement and benchmarking. (Reid and Sanders, 2002)(Feigenbaum, 1998)(Hazier and Render, 2011; Finch 2003, Evans, 1997).

Table 1: The three perspectives of quality management system

\begin{tabular}{|c|c|c|c|}
\hline Heading & $\begin{array}{l}\text { ISO 9000-2008 and } 2015 \\
\text { (draft) }\end{array}$ & Accreditation & $\begin{array}{l}\text { Researchers } \\
\text { contributions } \\
\end{array}$ \\
\hline $\begin{array}{l}\text { Elements/ } \\
\text { requirements }\end{array}$ & $\begin{array}{l}\text { I. ISO 9000-2008 } \\
\text { - Quality management system } \\
\text { - Management responsibility, } \\
\text { - Resource management } \\
\text { provisions, } \\
\text { - Infrastructure, } \\
\text { - Product realization } \\
\text { - Measurement, analysis and } \\
\text { improvement } \\
\text { II. ISO 9000 2015 } \\
\text { - Customer focus } \\
\text { - Leadership } \\
\text { - Engagement of people } \\
\text { - Process approach } \\
\text { - Improvement } \\
\text { - Evidence-based decision } \\
\text { making } \\
\text { - Relationship management }\end{array}$ & $\begin{array}{l}\text { I. Patient-Centered standards (8 } \\
\text { criteria) } \\
\text { International patient safety goals, } \\
\text {-Access to care and continuity of care, } \\
\text { - Patient and family rights, } \\
\text { - Assessment of patients, } \\
\text { - Care of patients, } \\
\text { - Anesthesia and surgical care, } \\
\text { - Medication management and use, } \\
\text { - Patient and family education. } \\
\text { Section II: Health care organization } \\
\text { management standards (6 criteria) } \\
\text { - Quality improvement and patient } \\
\text { safety } \\
\text { - Prevention and control of infections } \\
\text { - Governance, leadership, } \\
\text { and direction } \\
\text { - Facility management and safety } \\
\text { - Staff qualifications } \\
\text { - Management of communication and } \\
\text { information }\end{array}$ & $\begin{array}{l}\text { - Quality management } \\
\text { system } \\
\text { - Quality based } \\
\text { leadership } \\
\text { - Quality and } \\
\text { engagement of staff } \\
\text { - Relationship with } \\
\text { patients (customer) } \\
\text { - Relationships with } \\
\text { suppliers } \\
\text { - Continuous } \\
\text { improvement }\end{array}$ \\
\hline Approach & System-oriented & $\begin{array}{l}\text { Details oriented in a comprehensive } \\
\text { framework }\end{array}$ & $\begin{array}{l}\text { Focus on key focal } \\
\text { elements }\end{array}$ \\
\hline $\begin{array}{l}\text { Level of } \\
\text { treatment }\end{array}$ & Strategic and operational & $\begin{array}{l}\text { Systematic and more specific } \\
\text { procedures }\end{array}$ & $\begin{array}{l}\text { Strategic performance } \\
\text { and competitive } \\
\text { benchmarking }\end{array}$ \\
\hline $\begin{array}{l}\text { Evaluation } \\
\text { (1) }\end{array}$ & Operational & Technical & Open and unlimited \\
\hline $\begin{array}{l}\text { Evaluation } \\
\text { (2) }\end{array}$ & $\begin{array}{l}\text { Minimum requirements for } \\
\text { certificate }\end{array}$ & $\begin{array}{l}\text { Detailed and minimum requirements } \\
\text { for certificate }\end{array}$ & $\begin{array}{l}\text { Open requirements } \\
\text { for continuous } \\
\text { improvement }\end{array}$ \\
\hline
\end{tabular}

The most important question that should be asked here is: what is distinguishing each of these three perspectives? The ISO and accreditation perspectives are standardized systems based on the minimum necessary requirements to build a quality management system of measurable standardized specifications. Therefore, both perspectives seem to be highly concerned with details, and they are arranged in a hierarchal form starting with major, secondary, and operational requirements. Providing these requirements leads to the construction of a quality management system that meets the quality certification in both perspectives (ISO 9000 and accreditation). By contrast, the third perspective (TQM) is actually based on a strategic vision of quality management that is unrestricted by standards specifications (one model fits all types of organizations). It is recognized by its ability to ensure a continuous evolution and development of management quality elements based on the available data and company experience and practices. According to (Sun et al., 2004) TQM can attain a positive effect on five indicators of business performance: quality improvement, cost reduction, flexibility improvement, delivery improvement and customer service. In contrast, ISO can achieve two indicators of improvement: quality improvement and cost reduction.

\section{Method}

Variables of the study: This study based on three kinds of variables. Independent variables as predictor representing the six dimensions of TQM: strategic quality vision, quality and engagement of staff, relationship 
with customer, relationships with suppliers, and continuous improvement. These Six dimensions were developed relying upon three sources: ISO -9000, accreditation documents especially The Health Care Accreditation Council (HCAC), and researcher's contributions (Mehmood et al., 2014; Pramuka and Adawiyah, 2012; Prajogo and Sohal, 2003; Curkovic et al., 2000). There are three dependent (explained) variables representing the competitive advantage, innovation, competitive benchmarking and reputation. Finally, the moderator variables which are representing two essential elements: age and hospital size.

\subsection{Variables}

This study has considered five essential variables: TQM dimensions as independent or exogenous variables, innovation and reputation, as dependent or endogenous variables, and hospital age and size, as mediator variables. The relationship between TQM and innovation is not always a direct linear relationship as it seems at first sight.

This relationship is of a very complex nature and it might be positive or negative (Mushtaq et al., 2011; Prajogo, and Sohal, 2003; Powell, 1995). Regarding the main aspect of TQM, it is evident that the quality system rlys on limiting thinking to specification box, while innovation expands thinking to exceed that box. However, the TQM improvement cycle (plan-do-check-act) has also revealed some additional characteristics of that relationship, as the planned and implemented improvement process at the planning and doing stages, is transformed into a routine process at the standardization stage (acting). (Dahlgaard et al, 2007). Furthermore, the TQM approach that focuses on the customer or patient in the health service sector encourages innovation efforts for new ways in responding to the customer needs. By contrast the financial burdens associated with this service, create obstacles and challenges for the relationship between TQM and innovation (Moreira and Silva, 2015).

With a good financial performance and high level of customer satisfaction. This study also addresses innovation and its effect on the reputation of healthcare organizations. Reputation on one hand is an effective power for a distinguished competiveness, innovation, corporate success on the other hand it might lead to a dramatic failure due to poor reputation. It is the creator of a company competitive advantage. (Davies al, 2003); (Zaggl, 2017); (Gatzert and Schmit 2015). Companies have to build and enhance their reputational capital, as they need to build their physical and financial capital. The related literature indicates that the reputational capital contributes reasonably in maximizing opportunities and minimizing problems at the market place. (Doorley and Helio, 2007 p4). Generally, reputation is created and enhanced by several factors including the company ability to innovate. (Marquina et al, 2014). It is a function of many factors in front of which is innovation process. In this context, innovation contributes to build and improve reputation and creating an innovation-based reputation (Matera and Baena, 2015). The relationship between innovation and reputation was the main concern for many field studies. According to Dalton and Croft (2003, p10) innovation is an essential factor that plays an important role in building a company reputation along with competitive advantage.

\subsection{Sample}

The sample of this study comprises of four large hospitals in Amman: Jordan university hospital (founded in 1973), Al Khalidi hospital (founded in 1978), Specialty Hospital (founded in 1993), and Gardens hospital (founded in 2014).

Table 2: Sample characteristics

\begin{tabular}{llrrllrr}
\hline Charac. & Data & Freq. & $\%$ & Charac. & Data & Freq. & $\%$ \\
\hline \multirow{3}{*}{ Gender } & Male & 63 & 35.8 & Marital status & Single & 74 & 42.0 \\
& Female & 113 & 64.2 & & Married & 102 & 58.0 \\
& Total & 176 & 100.0 & & Total & 176 & 100.0 \\
& $<30$ & 71 & 44.5 & & G.P. & 34 & 8.8 \\
\multirow{5}{*}{ Age } & $30-39$ & 54 & 33.6 & & Specialist & 16 & 17.5 \\
& $40-49$ & 29 & 13.9 & Specialty & Subspecialist & 8 & 5.8 \\
& $50-59$ & 18 & 7.3 & & Nurse & 86 & 44.5 \\
& $>59$ & 4 & 0.7 & & Other (manager, & 32 & 23.4 \\
& & & & & officers) & 176 & 100 \\
Education & Total & 176 & 100 & & Total & 90 & 56.2 \\
& Sec. & 4 & 2.3 & Working & $<5$ years & 48 & 21.2 \\
& Dip. & 27 & 15,3 & experience & $5-9$ & 14 & 11.7 \\
& Bach. & 116 & 65.9 & & $10-15$ & 24 & 10.9 \\
& Mas. & 27 & 15.3 & & $>15$ & 176 & 100.0 \\
\hline
\end{tabular}


The first three of these companies have obtained the quality assurance certificate from The Health Care Accreditation Council (HCAC) in Jordan. (http://hcac.jo/en-us/Accreditation). The required data was collected using a deliberately designed and evaluated questionnaire where (200) questionnaires were distributed and (176) of which were returned. The distribution of respondents by hospital was (49), (42), (47), and (38) respectively. Table 2 shows the demographic characteristics of the sample.

\subsection{Questionnaire}

Questionnaire was the main tool for data Collection that was used by this study. It consists of three sections, the first covered demographical and functional characteristics (independent variables), the second Consists of 30 statements that measure the six TQM dimensions (independent variables), and the third section implies 18 statements that measure the three elements of the competitive advantages (dependent variables). The data of the two moderator variables (hospitals age and size) was obtained depending from the hospital website.

\subsection{Tests}

Table (3) illustrates the results of validity test to ensure collected data reliability for further statistical analysis and hypotheses testing.

- Construct validity: To ensure that the questionnaire measures what it designed for, the construct validity test was carried out. Table (3) portrays the results of the Construct Validity, Reliability, and Collinearity tests. The factors loadings values of the five TQM dimensions were ranged from (0.732) to (0.843) which are all larger than the acceptable factors loadings value limit of (0.50). These results clearly indicate that all the independent variables are valid and reliable for statistical analysis.

- Reliability test: To examine the internal consistency of the questionnaire statements that measure the TQM dimensions, Cronbach's alpha was conducted. Cronbach's alpha values were; (0.854) for quality system, (0.809) for quality leadership, (0.848) the medical and sanitary staff, $(0.876)$ for relationship with patient, (0.728) for relationship with suppliers, and (0.888) for continuous improvement. These results clarify that the consistency level of the questionnaire statements is acceptable as all Cronbach`s alpha values exceed the valid value limit of (0.60).

Collinearity test: This test aims to ensure the inexistence of internal correlation between the variables of the study because the existence of such correlation will negatively affect the ability of the model of the study to predict the impact of independent variables on dependent variables. As it is shown by table( 3$)$, the colinearity analysis results indicate that the consistent patterns of relationships among the variables (VIF < 10 for all TQM dimensions) are reliable.

Table 3: Construct validity, reliability and collinearity tests

\begin{tabular}{|c|c|c|c|c|c|c|}
\hline \multirow[b]{2}{*}{ Variables } & \multirow[b]{2}{*}{$\begin{array}{l}\text { Factor } \\
\text { loadings }\end{array}$} & \multicolumn{2}{|c|}{$\begin{array}{l}\text { Construct validity: } \\
\text { Component analysis: }\end{array}$} & \multirow{2}{*}{$\begin{array}{r}\text { Reliability } \\
\text { Test } \\
\text { Cronbach's } \\
\text { alpha }\end{array}$} & \multicolumn{2}{|c|}{ Collinearity test } \\
\hline & & Extraction & KMO & & Tolerance & VIF \\
\hline Quality system (QS) & 0.732 & 0.966 & & 0.854 & 0.592 & 1.968 \\
\hline Quality leadership $(\mathrm{QL})$ & 0.838 & 0.537 & & 0.809 & 0.418 & 2.394 \\
\hline Medical and sanitary Staff (QM) & 0.843 & 0.713 & & 0.848 & 0.393 & 2.543 \\
\hline Relationship with patient(RP) & 0.743 & 0.714 & 0.852 & 0.876 & 0.548 & 1.826 \\
\hline Relationships with suppliers(RS) & 0.799 & 0.606 & & 0.728 & 0.455 & 2.195 \\
\hline Continuous improvement $(\mathrm{CI})$ & 0.833 & 0.696 & & 0.888 & 0.426 & 2.345 \\
\hline
\end{tabular}

\subsection{Hypotheses testing}

The main hypotheses of this study are the following:

H1. There is a positive effect of TQM dimensions on hospital innovation.

H2: There is a positive effect of TQM dimensions on corporate hospital reputation.

H3. There is a positive effect of hospital innovation on corporate reputation.

H4. The age of the hospital mediates the relationship between TQM and innovation.

H5. The size of the hospital mediates the relationship between TQM and innovation.

To test the study hypotheses, path analysis with SPSS/Amos was used to determine the direct and indirect effects of exogenous (independent) variables on endogenous (dependent) variables which according to this study mean that TQM dimensions affect innovation which in turn affects reputation. This type of statistical analysis also uses to determine the effect of mediator variables on the relationships between exogenous (independent) variables and endogenous (dependent) variables. This study used path analysis to identify the direct or indirect effect of TQM dimensions (quality system QS, quality leadership QL, medical and sanitary staff $\mathrm{QM}$, relationship with patient RP, relationships with supplier's RS, and continuous improvement $\mathrm{CI}$ ) on 
innovation as a competitive advantage, and effect of innovation (as an antecedent or independent variable) and in turn innovation effect on corporate reputation (as a consequent or dependent variable). Two mediator variables (hospital age and size) were tested to determine their effect on the relationship between TQM dimensions and innovation. Path diagram is another feature of the path analysis as it presents all variables of the study in one path diagrams. For the first three hypotheses, figure 1 portrays the formational path model and the outcomes of the correlation analysis (covariance) for each double-headed arrow between each two dimensions of TQM, and the outcomes of the multiple regression analyses for each one head arrow.

$$
-176 \text { cases, } X^{2}=284.401
$$

Figure 1: Path diagram of TQM dimensions innovation (IN), and reputation (RE)

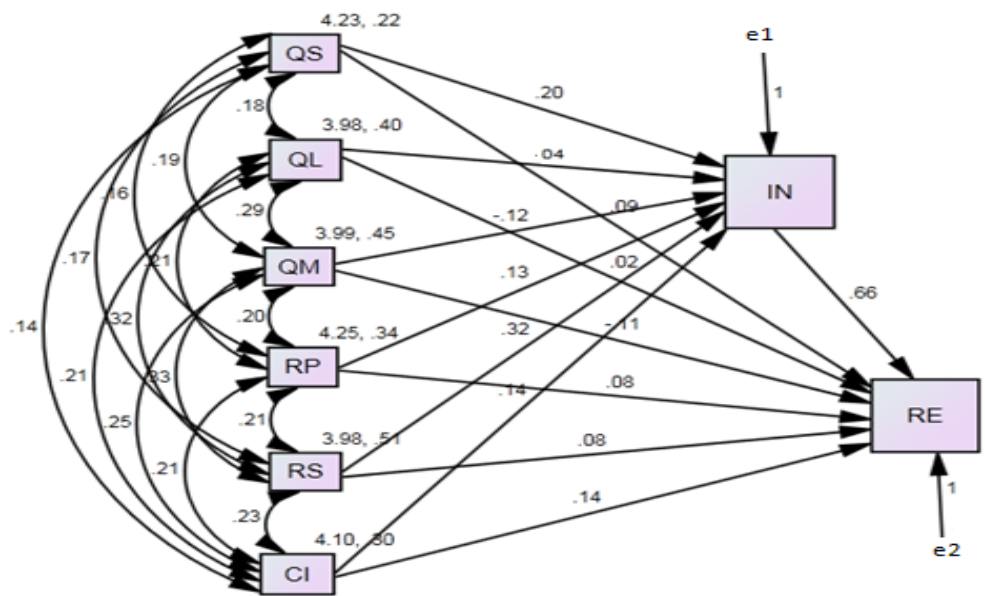

The path analysis results presented by table (4) (covariance of TQM dimensions) indicate that there are minor positive relationships between each pair of TQM dimensions. It would be rational to conclude that there is no multicollinearity problem.

Table 4: Covariance of TQM dimensions

\begin{tabular}{|c|c|c|c|c|c|c|}
\hline \multirow{2}{*}{ TQM Dimensions } & & & & \multicolumn{3}{|c|}{ Estimates of TQM Dimensions } \\
\hline & QS & QL & QM & $\mathrm{RP}$ & $\mathrm{RS}$ & $\mathrm{Cl}$ \\
\hline $\mathrm{QS}$ & 1.000 & & & & & \\
\hline $\mathrm{QL}$ & $0.150^{* * *}$ & 1.000 & & & & \\
\hline QM & $0.174^{* * *}$ & $0.288^{* * *}$ & 1.000 & & & \\
\hline $\mathrm{RP}$ & $0.142^{* * *}$ & $0.198^{* * *}$ & $0.187^{* * *}$ & 1.000 & & \\
\hline RS & $0.141^{* * *}$ & $0.316^{* * *}$ & $0,329 * * *$ & $0,189^{* * *}$ & 1.000 & \\
\hline $\mathrm{CI}$ & $0.129^{* * *}$ & $0.204^{* * *}$ & $0.252^{* * *}$ & $0.195^{* * *}$ & $0.228^{* * *}$ & 1.000 \\
\hline
\end{tabular}

(***) P- value $<0.001$

\section{H1: There is a positive effect of TQM dimensions on innovation.}

The adoption of TQM is consistent with many changes in the strategic vision, culture, and practices of the company, which has a positive impact on the employee's attitudes to improvement and innovation activities. However, TQM cannot be considered a necessary condition for innovation in all cases. The (H1) hypothesis attempts to determine the impact of TQM on innovation. The results of the regression analysis indicated that the five TQM dimensions (QS, QL, QM, RS, and $\mathrm{CI}$ ) have a positive effect on innovation (IN). While the sixth dimension (the relationship with patient) (RP) has an inverse relationship with innovation. The positive effect of TQM dimensions on innovation represented by beta values was; RS (0.29), CI (0.25), QS (0.21) to RS (0.15), and QL (0.09). By contrast there was a reverse effect of QM dimension of (medical and sanitary staff) on innovation as the beta value of this dimension was $(-0.28)$. For model fitting test, the results manifested that fitting indices were applicable and adequate to fit a model as fit $>$ indices which were ; goodness of fit (GFI = 0.747), Root Mean Square Residual $(\mathrm{RMR}=0.081)$ and Root Mean Square Error of Approximation (RMSEA= 0.042) (Kline, 1998; Bucker et al., 2015).

In the relationship between TQM and innovation, studies differed in their results. Many studies (Prajogo and Hong, 2008; Satish and Srinivasan, 2010) argued that the relationship was positive. While other studies confirmed a negative relationship between them, the interpretation of these results can be achieved through multidimensional TQM. Some of these dimensions (continuous improvement and relationship with customer) are working to improve innovation, while the concept of quality in the product or service that is based on conformity of specifications and quality system creates constraints on innovation, which means working outside specifications. 
Table 5: Regression weights: effect of TQM dimensions on innovation

\begin{tabular}{lrrr}
\hline Variables (path) & Mean estimate & Beta & P-value \\
\hline QS ----->IN & SQ: 3.920(0.46) & 0.20 & 0.000 \\
QL ---->IN & QL: 3.899(0.64) & 0.04 & 0.000 \\
QM ---->IN & QM: 4.175(0.69) & -0.12 & 0.000 \\
RP ----->IN & RP: 4.204(0.59) & 0.13 & 0.000 \\
RS ----->IN & RS: $4.049(0.73)$ & 0.32 & 0.000 \\
CI ----->IN & CI: 3.898(0.55) & 0.14 & 0.000 \\
\hline
\end{tabular}

- 176 cases, $X^{2}=284.401, d f=28$ (he minimum number of independent coordinates.

\section{H2: There is a positive effect of TQM dimensions on corporate reputation.}

TQM contributes significantly to maintain a competitive advantage based on high level of service quality and also greatly contributes to the improvement of the company's reputation. This hypothesis aims at determining the impact of services quality on hospital reputation. Path diagram and table (6) results plainly indicate that there is a positive effect of five TQM dimensions (QS, QL, RP, RS, and CI) on the hospital corporate reputation. at (P-value $<0.05$ ) level of significance. While the QM dimension (medical and sanitary Staff) has an adverse effect (Beta estimate $=\mathbf{- 1 1 1}$ ) on reputation. This reverse effect might be due to some incompatibility between the sample members (specialists, general practitioners, and nurses).

Table 6: Regression weights: effect of TQM dimensions on reputation (RE)

\begin{tabular}{lrrr}
\hline Variables (path) & Mean $(\mathrm{Sd})$ & Beta & P-value \\
\hline QS $----->$ RE & SQ: 3.920(0.46) & 0.09 & 0.000 \\
QL $---->$ RE & QL: 3.899(0.64) & 0.02 & 0.000 \\
QM $---->$ RE & QM: 4.175(0.69) & -0.11 & 0.000 \\
RP $----->$ RE & RP: $4.204(0.59)$ & 0.08 & 0.000 \\
RS $----->$ RE & RS: 4.049(0.73) & 0.08 & 0.000 \\
CI ----->RE & CI: 3.898(0.55) & $0-14$ & 0.000 \\
\hline
\end{tabular}

- The fit indices goodness-of-fit index: $\mathrm{GFI}=0.327, \mathrm{AGFI}=0.103, \mathrm{RMR}=0.182$ and $(\mathrm{RMSEA}=0.441)$ indicated acceptable model fit.

\section{H3. There is a positive effect of innovation on corporate reputation.}

Innovation is always a necessary achievement for business organizations regardless of the company ability to innovate weather it is high or low. As a matter of fact, the global demand for innovation is much greater than the supply. Innovation is an effective mean for creating what so call the new five forms suggested by Joseph Schumpeter for business organizations. The achievement of one or more of these five forms would make the organization able to build a distinguished competitive advantage at the market place. The contribution of innovation makes it a critical factor hypothesis suggests that there is a positive impact of innovation on the company's reputation. The regression analysis results illustrated by the path diagram and table (7) clarifies that there is a relatively strong positive impact of innovation on the company's reputation, as beta value was (0.66) at (p-value $<0.05)$ significance level.

Table 7: Effect of innovation on reputation (RE)

\begin{tabular}{lrrr}
\hline Variables (path) & Mean (Sd) & Beta & P-value \\
\hline IN ------>RE & IN: $4.183(0.60)$ & 0.660 & 0.020 \\
\hline
\end{tabular}

H4: Hospital age mediates the relationship between TQM dimensions and innovation.

The first mediator that can mediate on this relationship was the hospital age. The four hospitals which comprised the study sample were diversified in their foundation dates. The oldest hospital in its foundation date was the University Hospital of Jordan which was established in 1973, followed by the Khalidi Hospital in 1978, Specialty Hospital in 1993, and Gardens hospital (2014). Hypothesis (H4) was examined through two-phase test. The first, phase is to determine the direct effect of TQM dimensions on innovation without using the mediator variable, and the second phase was to calculate the indirect impact of TQM dimensions on innovation using the mediator variable.

Figure (2) and table (8) portray that the effect of TQM dimensions on innovation before introducing the mediator variable was high as (beta $=0.64$ ) on the other hand this effect has become greater as $($ beta $=0.66)$ after inserting the mediator variable. While the age of the hospital had a weak effect on the innovation with a value closer to zero (beta $=0.04$ ) at ( $p$-value $>0.05$ ) insignificant level. IT might be factual to conclude that the age of the hospital as a mediator has no effect on the relationship between TQM dimensions and innovation. 
Figure 3: Effect of TQM (all dimension) on innovation (IN) (without and with hospital size as a mediator variable)
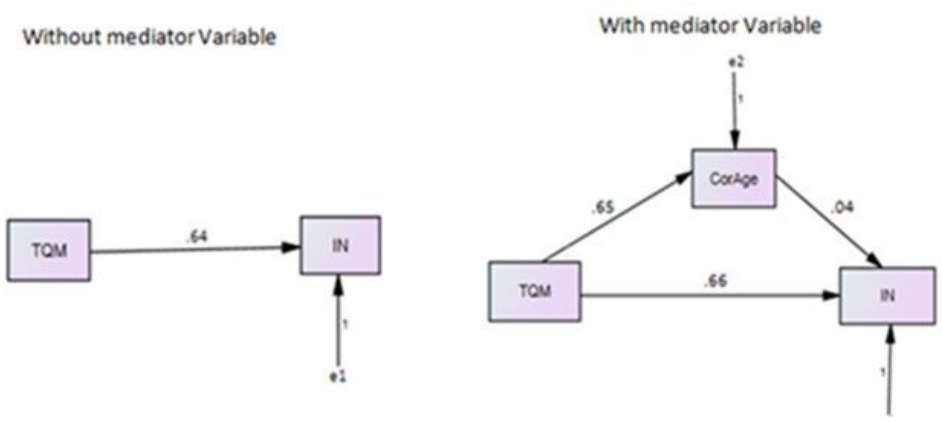

Table 8: Effect TQM (all dimensions) on innovation (IN) (with and without mediator Variable: hospital age)

\begin{tabular}{llrrrr}
\hline \multirow{2}{*}{ Hypothesis } & Without mediator variable & & & & \\
& Variables & Beta & S.E. & C.R. & P-value \\
\hline & TQM $>>>>$ IN & 0.636 & 0.077 & 8.221 & 0.000 \\
H4 & & & With mediator variable \\
& Variables & Beta & S.E. & C.R. & P-value \\
& TQM $>>>>$ IN & 0.663 & 0.081 & 8.216 & 0.000 \\
& TQM $>>>$ CroAge & 0.652 & 0,161 & 4.038 & 0.000 \\
CroAge $>>>>$ IN & -0.014 & 0.036 & -1.142 & 0.253 \\
\hline
\end{tabular}

H5: Hospital size mediates the relationship between TQM and innovation.

The four hospitals cover by this study is widely varied in their size (number of beds and employees). For test purposes the four hospitals were arranged according to their size, which was determined by number of beds and employees. According to this criterion, the four hospitals were arranged as follows: The University Hospital of Jordan with 547 beds and 2704 employees, the Specialty hospital with 209 beds and 830 employees, the Khalidi hospital with 160 beds and 700 employees and finally, the Gardens hospital with 165 beds and 500 employees. (www.hospital.ju.edu.jo),(www.kaaps.jo), (www.Wikipedia.org),(www.joheart/com). Similarly figure (2) and table (9), clearly present that there is a positive effect of TQM on innovation as (beta $=0.64$ ) before inserting the mediator variable (hospital size), This effect has become much greater as (beta $=0.75$ ) after inserting the mediator variable. On the other hand, the hospital size had a reverse effect on the hospital general reputation with a Beta value closer to zero (Beta $=\mathbf{- 0 . 0 5}$ ) at ( $\mathrm{p}$-value $>0.05)$ significant level. Once again, it would be true to conclude that the mediator variable (hospital size) has no effect on the relationship between $\mathrm{TQM}$ dimensions and innovation.

Figure 2: Effect of TQM (all dimensions) on innovation (IN) (without and with hospital size as a mediator variable)

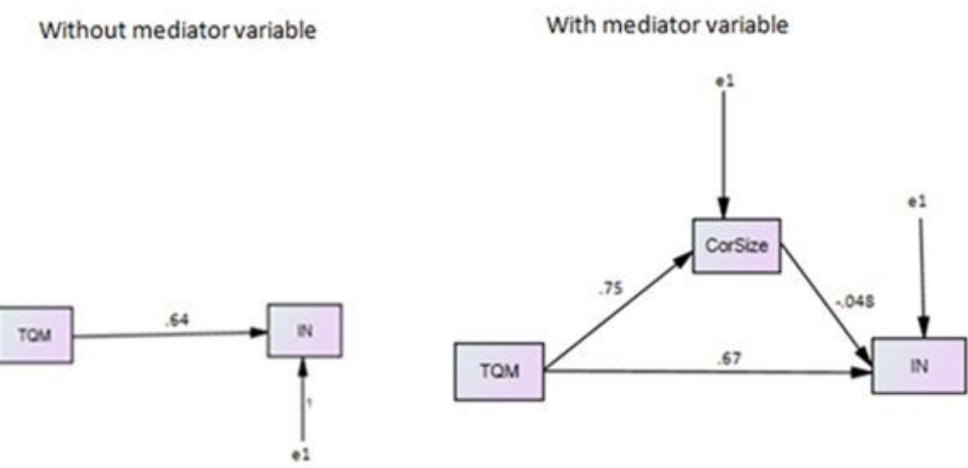

Table 9: Effect TQM (all dimensions) on innovation (IN) (with and without mediator Variable: hospital size)

\begin{tabular}{|c|c|c|c|c|c|}
\hline \multirow{2}{*}{ Hypothesis } & \multicolumn{5}{|l|}{ Without mediator variable } \\
\hline & Variables & Beta & S.E. & C.R. & P-value \\
\hline \multirow{6}{*}{ H5 } & TQM $>>>>$ IN & 0.636 & 0.077 & 8.211 & 0.000 \\
\hline & \multicolumn{5}{|c|}{ With mediator variable } \\
\hline & Variables & Beta & S.E. & C.R. & P-value \\
\hline & TQM $>>>>$ IN & 0.672 & 0.082 & 8.226 & 0.000 \\
\hline & TQM $>>>>$ CroSize & 0.756 & 0.162 & 4.669 & 0.000 \\
\hline & CroSize $>>>>$ IN & -0.048 & 0.036 & -1.331 & 0.183 \\
\hline
\end{tabular}




\section{Discussion}

TQM has become a key element for fruitful organizational performance () and a key indicator of the company's ability to compete at the market place. It also be considered as a competitive advantage () or a source of competitive advantage (Korankye, 2013). This is because TQM has a great impact on customer satisfaction, competitive power, and innovation of the company. However, TQM has been in a continuous confrontation with many obstacles and problems, and in many cases these challenges were accompanied by negative assessment of some field studies results which expanded these challenges (Iaquinto, 1999; Powell, 1995, Tarnow and Wiley, 1991). This study has realized that there are three main sources for quality management practices: the ISO 9000-2008 and 2015, the accreditation certificate, and the contributions of researchers to identify and develop TQM elements. This study revealed that the ISO 9000 and accreditation certificate are both representing the standardized systems. These systems greatly rely upon providing the minimum necessary requirements for building a quality management system that characterized by its measurable standardized specifications. In comparison with those two resources researchers' contributions are characterized by its continuous evolution for all concepts and practices of quality system with new additional suggestions and improvements that go beyond the standards and specific requirements of ISO 9000 and accreditation systems. Quality management is the most important development that the industry and services sectors have ever seen. By the 1980s-decade, quality management has urged companies to adopt the strategic vision of quality in which considers quality as a competitive advantage. The findings of this study clearly indicate that five dimensions of TQM (QS, QL, RP, RS, and CI) have a positive impact on hospital innovation and reputation. This result is symmetrical to the results of many previous field studies (Prajogo and suhal, 2003; Hung et al., 2010; Abrunhosa and Sa, 2008; Bon and Mustafa, 2013; Silva et al., 2014) and it can be consider as a motive for business organizations in general and hospital in particular to implement a continuous improvement strategy: CI (the sixth dimension of TQM). The CI concept is much closer to innovation because it requires a continuous changes and modifications to improve health service. Furthermore, TQM dimensions have a positive effect on hospital reputation since TQM system contributes meaningfully to the improvement of the overall company performance that would lead to improve its reputation. The relationships with medical and sanitary staff (the third dimension of study model) had an adverse effect on innovation. This result might be related to some quality determinants concerning quality burdens of TQM system applications that may cause the negative impact on staff attitudes toward the implementation of quality system.

\section{References}

Aboyassin, N. A., Najm, A. N., and Alhameidiyeen, M. M.S. (2017). Toward a Model for Managing and Measuring Intangibles, Volume: XIII, Issue: 1, pp. 84-110.

Abrunhosa, A. and Sa, P. M. 2008. Are TQM principles supporting innovation in the Portuguese footwear industry? Technovation, Vol. (28), 208-221

Barnes, F.C. (2000). ISO 9000 Myth and Reality. In: R.K. Shukla (Eds.), Production and Operations Management, Dushkin: McGraw-Hill.

Berger, A. (1997). Continuous improvement and kaizen: standardization and organizational designs. Journal of Integrated Manufacturing Systems, Vol 8 No 2, pp 110-117. https://doi.org/10.1108/09576069710165792

Birinshaw, J., Hamel, G. and Mol, M. J. (2008). Management Innovation, Academy of Management Review, 33 (4), 825-845. https://doi.org/10.5465/AMR.2008.34421969

Bon, A. T., and. Mustafa, E. M.A, (2013). Impact of Total Quality Management on Innovation in Service Organizations: Literature review and New Conceptual Framework. Procedia Engineering, (53, 516 - 529). https://doi.org/10.1016/j.proeng.2013.02.067

Crosby, P. B. (1979). Quality is free: the art of making quality certain. New York: McGraw-Hill.

Dahlgaard, J. J., Kristensen, K., and Kanji, G. K. (2007). Fundamentals of Total Quality Management, London: Taylor \& Francis.

Dalton, J., and Croft, S. (2003). Managing Corporate Reputation, London: Thorogood.

Davies, G. C., Rosa, S., Rui V., and Roper S. (2003). Corporate Reputation and Competitiveness. London: Routledge. https://doi.org/10.4324/9780203218112_chapter_2

Doorley, J., and Garcia, H. F. (2007). Reputation Management. New York: Taylor \& Francis Group.

Evans, J. (1997). Operations Management. New York: West Publishing Co.

Feigenbaum, A.V. (1998). Total Quality Development into the 1990s; An International Perspective. In Chase R.L. (Eds.), Total Quality Management: An IFS Executive Briefing, New York: Springer.

Finch, B.J. (2007). Operations Now.com. Boston: McGraw-Hill Higher Education.

Gatzert, N., and Schmit, J. (2016). Supporting strategic success through enterprise-wide reputation risk management. The Journal of Risk Finance, 17 (1), 26-45. https://doi.org/10.1108/JRF-09-2015-0083

Goldhar, J.D., and Jelinek, M. (1983). Plan for Economies of Scope. Harvard Business Review, November.

Heizer, J., and Render, B. (2011). Operations Management. New Jersey: Prentice-Hall.

Holm, B. (2013). ISO 9001:2015 Draft International Standard Overview. Available at: http://www.dnvgl.com (accessed at Jan 20, 2017). 
Hoyle, D. (2011). ISO 9000 Quality Systems Handbook. Oxford: Butterworth-Heinemann.

Hung, R, Yu-Yuan, L., Bella Y., Fang, S., and McLean, G. N. (2010). Knowledge as a Facilitator for Enhancing Innovation Performance through Total Quality Management. The Quality Management and Business Excellence, 21(4), 425-438. https://doi.org/10.1080/14783361003606795

Iaquinto, A.L. (1999). Win a Quality Award and Lose Your Competitive Advantage. Strategic Change, Vol. (8), 95 101. https://doi.org/10.1002/(SICI)1099-1697(199903/04)8:2<95:AID-JSC418>3.0.CO;2-K

ISO (2008). Quality management systems - Requirements (ISO 9001:2008), Geneva.

ISO (2015). ISO 9001:2015. How to Use It. Geneva.

Joint Commission International: JCI (2014). Joint Commission International Accreditation Standards for Hospitals. Available at: https://www.jointcommissioninternational.org (accessed on July 25, 2017).

Juran, J. (1992). Made in USA: a renaissance in quality. Harvard Business Review, July-August, 42-50.

Juran, J., Godfrey, B., Hoogstoel, R.E., and Schilling, E.G. (1999). Juran's Quality Control Handbook. New York: McGraw-Hill.

Korankye, A.A. (2013). Total Quality Management (TQM): A Source of Competitive Advantage: A Comparative Study of Manufacturing and Service Firms in Ghana. International Journal of Asian Social Science, 2013, 3(6),1293-1305.

Marquina, P., Bahamonde, R.A., and Bellido, I.V.(2014). A New Approach for Measuring Corporate Reputation. Revista de Administracao Empresa, Jan-Feb, 53-66 (Article in English).

Mehmood, Shahid, Qadeer, Fairal, and Ahmad, A. (2014). Relationship between TQM Dimensions and Organizational Performance. Pakistan Journal of Commerce and Social Sciences, 8 (3), 662-679.

Mehra, S., Hoffman, J. M., and Sirias, D. (2001). TQM as a management strategy for the next millennia. International Journal of Operations \& Production Management, 21 (5/6), 855-876. https://doi.org/10.1108/01443570110390534

Moreira, A. C., and Silva, P. M. (2015). The trust-commitment challenge in service quality-loyalty relationships. International Journal of Health Care Quality Assurance, $28 \quad$ (3), $253 \quad-\quad 266$. https://doi.org/10.1108/IJHCQA-02-2014-0017

Munizu, M. (2013). The Impact of Total Quality Management Practices towards Competitive Advantage and Organizational Performance: Case of Fishery Industry in South Sulawesi Province of Indonesia. Pakistan Journal of Commerce and Social Sciences, 7 (1), 184-197.

Mushtaq, N., Peng, W. W., and Lin, S. K.L. (2011). Exploring the Lost Link between TQM Innovation and Organization Financial Performance through Non- Measures. International Conference on Innovation. Management and Service, Singapore: IACSIT Press.

Parasuraman, A., Berry, L. L., and Zeithaml, V. A. (1991). Refinement and Reassessment of the SERVQUAL Scale. Journal of Retailing, 67 (4), 420-450.

Parasuraman, A., Berry, L. L. and Zeithaml, V. A., (1993). More on Improving Service Quality Measurement. Journal of Retailing, 69(2), 140-147. https://doi.org/10.1016/S0022-4359(05)80007-7

Parasuraman, A., Zeithaml, V. A. and Berry, L. L. (1994). Reassessment of Expectations as a Comparison Standard in Measuring Service Quality: Implications for Future Research. Journal of Marketing, 58 (1),111-124. https://doi.org/10.2307/1252255

Parasuraman, A., Zeithaml, V. A. and Berry, L. L. (1988). SERVQUAL: A Multiple-item Scale for Measuring Customers Perceptions of Service Quality. Journal of Retailing, 64 (1), 12-40.

Parasuraman, A., Zeithaml, V. A. and Berry, L. L., (1985). A Conceptual Model of Service Quality and its Implications for Future Research. Journal of Marketing, 49 (4) ,41-50. https://doi.org/10.2307/1251430

Powell, T.C. (1995). TQM as Competitive Advantage: A Review and Emprical Study. Strategic Management Journal, 16 (1), 15-37. https://doi.org/10.1002/smj.4250160105

Prajogo, D.I., and Sohal. A.S. (2003). The relationship between TQM practices, quality performance, and innovation performance: An empirical examination. International Journal of Quality \& Reliability Management, 20 (8), 901-918. https://doi.org/10.1108/02656710310493625

Pramuka, B. A., and Adawiyah, W. R. (2012). The Human Related Dimensions of TQM in Service Settings. American International Journal of Contemporary Research, 2 (1) January 124-131.

Reed, R., Lemakb, D. J., and Meroc, N. P. (2000). Total quality management and sustainable competitive advantage. Journal of Quality Management 5, 5-26. https://doi.org/10.1016/S1084-8568(00)00010-9

Reid, R.D., and Sanders, N.R. (2002). Operations Management: An Integrated Approach. New York: John Wiley and Sons.

Satish, K. P., and Srinivasan, R. (2010). Total quality Management and Innovation performance: An Empirical Study on the interrelationships and Effects. South Asian Journal of management, 17, (3), 8- 22.

Silva, G. Miranda, Gomes, Paulo J. L., Luís F., and Zulema L. P. (2014). The role of TQM in Strategic Product Innovation: An Empirical Assessment. International Journal of Operations \& Production Management, 34 (10), 1307-1337. https://doi.org/10.1108/IJOPM-03-2012-0098

Sparks, R., and Legault, R. (1993), A definition of quality for total customer satisfaction: the bridge between manufacturer and customer. SAM Advanced Management Journal, 58 (1), 16-21. 
Stevenson, W.J. (2011). Operations Management. McGraw-Hill/Irwin, Boston.

Sun, H. et al. (2004). The trajectory of implementing ISO 9000 standards versus total quality management in Western Europe. The International Journal of Quality \& Reliability Management, 21 (2/3), 131-153. https://doi.org/10.1108/02656710410516952

Tornow, W.W., and.Wiley, J.W. (1991). Service Quality and Management Practices. Human Resources Planning, 14 (2), 105-115.

Tricker, R. (2010). ISO 9001: 2008 for Small Businesses, Oxford: Elsevier Ltd.

Zaggl, A. (2017). Manipulation of explicit reputation in innovation and knowledge exchange communities: The example of referencing in science Michael. Research Policy 46, 970-983. https://doi.org/10.1016/j.respol. 2017.02.009 